\title{
Regulation of Insulin Receptor Substrate-1 in Liver and Muscle of Animal Models of Insulin Resistance
}

\author{
Mario J. A. Saad, Eiichi Araki, Montserrat Miralpeix, Paul L. Rothenberg, Morris F. White, and C. Ronald Kahn \\ Research Division, Joslin Diabetes Center, Department of Medicine, Brigham and Women's Hospital, \\ and Harvard Medical School, Boston, Massachusetts 02215
}

\section{Abstract}

Insulin rapidly stimulates tyrosine phosphorylation of a protein of $\sim 185 \mathrm{kD}$ in most cell types. This protein, termed insulin receptor substrate-1 (IRS-1), has been implicated in insulin signal transmission based on studies with insulin receptor mutants. In the present study we have examined the levels of IRS1 and the phosphorylation state of insulin receptor and IRS-1 in liver and muscle after insulin stimulation in vivo in two rat models of insulin resistance, i.e., insulinopenic diabetes and fasting, and a mouse model of non-insulin-dependent diabetes mellitus (ob/ob) by immunoblotting with anti-peptide antibodies to IRS-1 and anti-phosphotyrosine antibodies.

As previously described, there was an increase in insulin binding and a parallel increase in insulin-stimulated receptor phosphorylation in muscle of fasting and streptozotocin-induced (STZ) diabetic rats. There was also a modest increase in overall receptor phosphorylation in liver in these two models, but when normalized for the increase in binding, receptor phosphorylation was decreased, in liver and muscle of STZ diabetes and in liver of $72 \mathrm{~h}$ fasted rats. In the hyperinsulinemic ob/ob mouse there was a decrease in insulin binding and receptor phosphorylation in both liver and muscle. The tyrosyl phosphorylation of IRS-1 after insulin stimulation reflected an amplification of the receptor phosphorylation in liver and muscle of hypoinsulinemic animals (fasting and STZ diabetes) with a twofold increase, and showed a significant reduction $(\sim \mathbf{5 0 \%})$ in liver and muscle of ob/ob mouse. By contrast, the levels of IRS-1 protein showed a tissue specific regulation with a decreased level in muscle and an increased level in liver in hypoinsulinemic states of insulin resistance, and decreased levels in liver in the hyperinsulinemic ob/ob mouse. These data indicate that: $(a)$ IRS-1 protein levels are differentially regulated in liver and muscle; $(b)$ insulin levels may play a role in this differential regulation of IRS-1; (c) IRS-1 phosphorylation depends more on insulin receptor kinase activity than IRS-1 protein levels; and $(d)$ reduced IRS-1 phosphorylation in liver and muscle may play a role in insulin-resistant states, especially of the ob/ob mice. (J. Clin. Invest. 1992. 90:1839-1849.) Key words: diabetes • fasting • insulin resistance • insulin receptor kinase $\bullet$ insulin receptor substrate $\bullet$ obesity

Dr. Rothenberg's current address is Department of Pathology and Laboratory Medicine, University of Pennsylvania School of Medicine, Philadelphia, PA 19104.

Address reprint requests to Dr. Kahn, Joslin Diabetes Center, One Joslin Place, Boston, MA 02215.

Received for publication 29 January 1992 and in revised form 13 May 1992.

J. Clin. Invest.

(c) The American Society for Clinical Investigation, Inc.

$0021-9738 / 92 / 11 / 1839 / 11 \$ 2.00$

Volume 90, November 1992, 1839-1849

\section{Introduction}

Insulin resistance is characteristic of many disease states including non-insulin-dependent diabetes mellitus (NIDDM), ${ }^{1}$ uncontrolled insulin-dependent diabetes, obesity, and prolonged fasting (1-4). Although various defects in insulin action have been reported in these conditions, the exact mechanisms involved in the insulin resistance have not been adequately defined.

Insulin initiates its metabolic and growth-promoting effects by binding to the $\alpha$ subunit of its tetrameric receptor (5), thereby activating the kinase in the $\beta$ subunit, which in turn catalyzes the intramolecular autophosphorylation of specific tyrosine residues of the $\beta$ subunit, further enhancing the tyrosine kinase activity of the receptor toward other protein substrates (5-7). Considerable evidence demonstrates that insulin receptor tyrosine kinase activity is essential for many, if not all, of the biological effects of insulin (8-10).

Although many purified proteins and synthetic peptides can be phosphorylated in vitro by isolated insulin receptors (11), these reactions do not occur in vivo, and thus their physiological significance is uncertain. In most cells, insulin stimulates tyrosine phosphorylation of a cytoplasmic protein with a relative molecular mass between 165 and $185 \mathrm{kD}$, collectively called pp 185 (12-19). Our laboratory recently cloned a component of the pp185 band termed insulin receptor substrate-1 (IRS-1) (20).

Although decreased insulin receptor kinase activity has been reported in various insulin resistant states, in most studies the receptors were partially purified, and then the kinase assays were performed in vitro using exogenous phosphoacceptor substrates such as histones (21-23). Thus, the role of endogenous substrate for the insulin receptor, IRS-1, has not been examined in insulin-resistant states.

Taking advantage of the recent sequence data, we have prepared anti-peptide antibodies to IRS-1. By using these along with anti-phosphotyrosine antibodies, it is possible to directly assess insulin-stimulated tyrosine phosphorylation of both the insulin receptor and its substrate IRS-1. In the present study we examined the phosphorylation state of the receptor and IRS-1 after insulin stimulation in vivo and also the levels of this protein in liver and muscle in two hypoinsulinemic states with altered insulin action, i.e., insulinopenic diabetes and fasting, and in the hyperinsulinemic, insulin resistance ob/ob mouse model of NIDDM.

\section{Methods}

Materials. Reagents for SDS-PAGE and immunoblotting apparatus were from Bio-Rad Laboratories (Richmond, CA). Streptozotocin,

1. Abbreviations used in this paper: IRS-1, insulin receptor substrate-1; NIDDM, non-insulin-dependent diabetes mellitus; STZ, streptozotocin. 
Hepes, PMSF, aprotinin, and DTT were from Sigma Chemical Co. (St. Louis, MO). Sodium amobarbital and human recombinant insulin (Humulin R) were from Eli Lilly \& Co. (Indianapolis, IN). ${ }^{125}$ I-protein A was from ICN Biomedical (Costa Mesa, CA). Nitrocellulose (BA85, $0.2 \mu \mathrm{m}$ ) was from Schleicher \& Schuell, Inc. (Keene, NH). Male Sprague-Dawley rats were from Charles River Breeding Laboratories, Inc., (Wilmington, MA). Male obese hyperglycemic mice (C57B1 / 6J $\mathrm{ob} / \mathrm{ob})$ and their lean matched controls $(\mathrm{ob} /+)$ were purchased from Jackson Laboratory (Bar Harbor, ME). Polyclonal anti-phosphotyrosine antibodies were raised in rabbits and affinity purified on phosphotyramine columns as described by Pang et al. (24). Anti-IRS-1 antibodies were raised in rabbits using a synthetic peptide derived from amino acid sequence (YIPGATMGTSPALTGDEAA) corresponding to residues 489-507 of the protein, and affinity purified on a column prepared by coupling the synthetic peptide to Affi-Gel 10 as previously described (25).

Animals. Male rats (130-180 g) and mouse (6-8 wk) were fed standard rodent chow and water ad libitum. Food was withdrawn 12 $14 \mathrm{~h}$ before experiments with the diabetic rats and ob/ob mouse and their respective controls. In the experiment on starvation, the rats were fed (controls) or fasted for 24,48 , and $72 \mathrm{~h}$. Diabetes was induced with streptozotocin (STZ) in citrate buffer, $\mathrm{pH} 4.5$, administered intraperitoneally in a single dose of $100 \mathrm{mg} / \mathrm{kg}$ body wt to overnight fasted rats. Diabetic rats were studied $7 \mathrm{~d}$ after streptozotocin injection.

Methods. Rats and mice were anesthetized with sodium amobarbital ( 15 and $20 \mathrm{mg} / \mathrm{kg}$ of body weight intraperitoneally, respectively) and were used in experiments 10-15 min later, i.e., as soon as anesthesia was assured by loss of pedal and corneal reflexes. The abdominal cavity was opened, the portal vein was exposed, and $1 \mathrm{ml}$ of normal saline $(0.9 \% \mathrm{NaCl})$ with or without $10^{-5} \mathrm{M}$ insulin was injected. At 30 s, the livers were removed, minced coarsely, and homogenized immediately in $\sim 10 \times$ vol of solubilization buffer $A$ in a water bath maintained at $100^{\circ} \mathrm{C}$ with a Polytron PTA 20S generator (model PT 10/35; Brinkmann Instruments, Inc., Westbury, NY) operated at maximum speed ( setting 10) for $30 \mathrm{~s}$. The solubilization buffer $\mathrm{A}$ was composed of $1 \%$ SDS, $50 \mathrm{mM}$ Hepes ( $\mathrm{pH} 7.4$ ), $100 \mathrm{mM}$ sodium pyrophosphate, 100 $\mathrm{mM}$ sodium fluoride, $10 \mathrm{mM}$ EDTA, and $10 \mathrm{mM}$ sodium vanadate. The homogenate was heated further to boiling for $10 \mathrm{~min}$ and then cooled in an ice bath for $\mathbf{4 0}$ minutes.

Approximately $2 \mathrm{~min}$ after injection, hindlimb muscles were quickly excised, and frozen in liquid nitrogen. At $4^{\circ} \mathrm{C}$ the frozen muscles were ground into a fine powder, then homogenized by a polytron in $6 \times$ vol of homogenization buffer B (same as buffer A except that $1 \%$ Triton-X 100 replaced $1 \%$ SDS and $2 \mathrm{mM}$ PMSF and $0.1 \mathrm{mg} / \mathrm{ml}$ aprotinin were added ). Both extracts were centrifuged at $55,000 \mathrm{rpm}$ at $4^{\circ} \mathrm{C}$ in a model 70.1 Ti rotor (Beckman Instruments, Inc., Fullerton, CA) for $60 \mathrm{~min}$ to remove insoluble material, and the supernatant was used as a sample.

In preliminary experiments we showed that the maximal phosphorylation for IRS- 1 occurs between 30 and $60 \mathrm{~s}$ in liver and between 1 and $4 \mathrm{~min}$ in muscle after insulin infusion. The doses that give these maximal stimulation are $10^{-6} \mathrm{M}$ and $10^{-5} \mathrm{M}$ insulin for liver and muscle, respectively. In that we infused into the portal vein $10^{-5} \mathrm{M}$ insulin and extracted liver at $30 \mathrm{~s}$ and muscle at $2 \mathrm{~min}$, the tissue sampling was done at the peak of phosphorylation events.

In every disease state studied the livers were extracted in a way identical to that of muscle, and the supernatant solutions of the muscle and livers were used for immunoprecipitation with anti-IRS-1 antibody. The samples were then treated with Laemmli sample buffer (26) with $100 \mathrm{mM}$ DTT and heated in a boiling water bath for $4 \mathrm{~min}$. For total extracts, similar size aliquots of sample ( $150 \mu \mathrm{g}$ of protein $)$ were subjected to SDS-PAGE (6\% Tris acrylamide) in a Bio-Rad Laboratories miniature slab gel apparatus (Mini-Protean). Molecular mass standards were myosin (205 kD), $\beta$-galactosidase ( $116 \mathrm{kD})$, bovine serum albumin $(80 \mathrm{kD})$, and ovalbumin $(49.5 \mathrm{kD})$.

Electrotransfer of proteins from the gel to nitrocellulose was performed for $1 \mathrm{~h}$ at $90 \mathrm{~V}$ (constant) in the Bio-Rad Laboratories miniature transfer apparatus (Mini-Protean) as described by Towbin et al.
(27) but with $0.02 \%$ SDS added to the transfer buffer to enhance elution of high molecular mass proteins. Nonspecific protein binding to the nitrocellulose was reduced by preincubating the filter overnight at $4^{\circ} \mathrm{C}$ in blocking buffer ( $3 \% \mathrm{BSA}, 10 \mathrm{mM}$ Tris, $150 \mathrm{mM} \mathrm{NaCl}$, and $0.02 \%$ Tween 20 ). The nitrocellulose blot was incubated with antiphosphotyrosine antibodies $(\alpha \mathrm{pY} 0.3 \mu \mathrm{g} / \mathrm{ml})$ or with anti-IRS-1 antibodies $(\alpha \mathrm{p} 800.3 \mu \mathrm{g} / \mathrm{ml})$ diluted in blocking buffer for $4 \mathrm{~h}$ at $22^{\circ} \mathrm{C}$ and washed for $60 \mathrm{~min}$ with the blocking buffer without BSA. The blots were then incubated with $2 \mu \mathrm{Ci}$ of ${ }^{125} \mathrm{I}$-protein $\mathrm{A}(30 \mu \mathrm{Ci} / \mu \mathrm{g})$ in $10 \mathrm{ml}$ of blocking buffer for $1 \mathrm{~h}$ at $22^{\circ} \mathrm{C}$ and then washed again as described above for $2 \mathrm{~h} .{ }^{125} \mathrm{I}$-protein $\mathrm{A}$ bound to the anti-phosphotyrosine and anti-IRS-1 antibodies was detected by autoradiography using preflashed XAR film (Eastman Kodak Co., Rochester, NY) with Cronex Lightning Plus (DuPont Co., Wilmington, DE) intensifying screens at $-70^{\circ} \mathrm{C}$ for $12-48 \mathrm{~h}$. Band intensities were quantitated by optical densitometry (model GS 300; Hoefer Scientific Instruments, Inc., San Francisco, CA) of the developed autoradiogram.

Insulin binding. The purified plasma membrane fractions of liver and muscle were prepared as previously described (28). The tissues were extracted from rats and mouse not injected with insulin. Aliquots of $200 \mu \mathrm{l}$ of purified plasma membrane $(0.5 \mathrm{mg}$ protein $/ \mathrm{ml})$ were incubated overnight at $4^{\circ} \mathrm{C}$ with ${ }^{125} \mathrm{I}$-insulin at $0.1-1 \mathrm{nM}$ in the presence and absence of $1 \times 10^{-5} \mathrm{M}$ unlabeled insulin. The assay was terminated by centrifugation of the tubes at $9,000 \mathrm{~g}$ for $3 \mathrm{~min}$. The pellets were washed twice by resuspension in washing buffer $(150 \mathrm{mM}$ $\mathrm{NaCl}, 50 \mathrm{nM}$ Hepes, $\mathrm{pH} \mathrm{7.4}$, and $1 \mathrm{mg} / \mathrm{ml}$ albumin ) at $4^{\circ} \mathrm{C}$, centrifuged, and the pellets were counted. Results are expressed as percentage of insulin bound compared to controls.

Cell culture. Chinese hamster ovary (CHO) cells that expressed high levels of surface insulin receptors (CHO/HIRC) (29) were cultured in 10-cm dishes (Nunc, Copenhagen, Denmark) in F12 medium supplemented with $10 \%$ fetal bovine serum (Gibco Laboratories, Grand Island, $\mathrm{NY}$ ) at $37^{\circ} \mathrm{C}$ in a $5 \% \mathrm{CO}_{2}$ incubator. For experiments, $90 \%$ confluent cultures ( $10^{6}$ cells) were serum deprived for 14-16 h before hormone stimulation, extraction, and analysis. Insulin (final concentration $10^{-7} \mathrm{M}$ ) was added, and the incubation was continued at $37^{\circ} \mathrm{C}$ for $1 \mathrm{~min}$. The cell monolayers were frozen with liquid nitrogen, thawed, and homogenized immediately with $2 \mathrm{ml}$ of the same extraction buffer used to extract muscle. The cells were scraped from the dishes and insoluble material was sedimentated by centrifugation at $50,000 \mathrm{rpm}$ in a model $70.1 \mathrm{Ti}$ rotor for $60 \mathrm{~min}$. The supernatant was treated with Laemmli sample buffer with $100 \mathrm{mM}$ DTT and heated in a boiling water bath for $4 \mathrm{~min}$. Equal aliquots ( $150 \mu \mathrm{g}$ of protein) of samples from $\mathrm{CHO} / \mathrm{HIRC}$ cells and liver and muscle of rats injected with insulin were subjected to SDS-PAGE and immunoblotting with anti-IRS-1 antibody as described above.

Other. Plasma glucose levels were determined with a Beckman Glucose Analyser (Beckman Instruments, Inc., Palo Alto, CA) on blood samples obtained when the animals were killed. Insulin was determined by a standard radioimmunoassay as previously described (30). Protein determination was performed by the Bradford dye method (31) using the Bio-Rad Laboratories reagent and BSA as the standard.

Statistical analysis. Experiments were always performed studying the physiological or pathological group of animals in parallel with a control group. Comparisons between fed (0) and fasted (24-72 h), controls vs. diabetics, and ob/+ vs. ob/ob were made using paired and unpaired $t$ test.

\section{Results}

Assay systems with anti-phosphotyrosine and anti-IRS-1 antibodies. Fig. $1 A$ shows the phosphotyrosine proteins in rat liver and muscle before and after intraportal insulin injection. In the basal state a closely spaced doublet with molecular mass between 110 and $120 \mathrm{kD}$ was observed in the SDS extracts of livers. We have referred to these bands collectively as pp120. After intraportal insulin injection $\left(10^{-5} \mathrm{M}\right)$, a $95-\mathrm{kD}$ band 

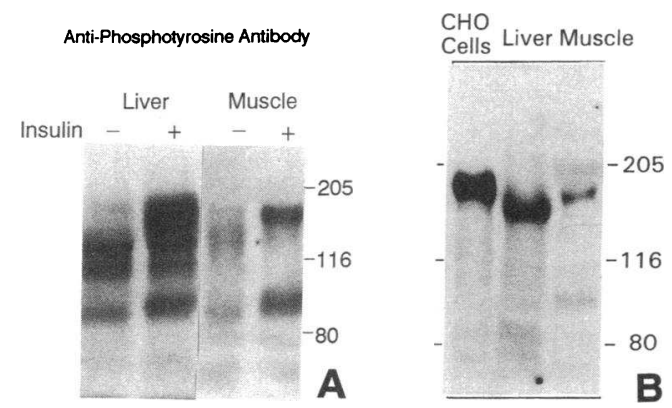

Figure 1. $(A)$ Insulin-stimulated tyrosine phosphorylation in intact liver and muscle from normal rats. The proteins from the liver and muscle were isolated as described in Methods. Briefly, rats were anesthetized and the abdominal wall was incised to expose the viscera. Normal saline (lanes marked "-") or $10^{-5} \mathrm{M}$ insulin (lanes marked "+") was infused into portal vein as a bolus injection and $30 \mathrm{~s}$ later liver was excised and homogenized in extraction buffer $\mathrm{A}$ at $100^{\circ} \mathrm{C}$ for $5 \mathrm{~min}$, and $2 \mathrm{~min}$ later muscles were excised and homogenized in extraction buffer $B$ at $4^{\circ} \mathrm{C}$. After centrifugation aliquots with same amount of protein were resolved on 6\% SDS-polyacrylamide gel, transferred to nitrocellulose, and detected with anti-phosphotyrosine antibodies and ${ }^{125}$ I-protein $A$ and subjected to autoradiography. $(B)$ Molecular heterogeneity of IRS-1 in CHO cells, liver, and muscle. The proteins from $\mathrm{CHO}$ cells, liver, and muscle were isolated as described previously. Aliquots normalized per protein were resolved on 6\% SDS-polyacrylamide gel, transferred to nitrocellulose, and detected with anti-peptide 80 antibody and ${ }^{125} \mathrm{I}$-protein $\mathrm{A}$ and subjected to autoradiography. $M_{\mathrm{r}}$ bands given at right are in $\mathrm{kD}$.

previously identified as the insulin receptor $\beta$ subunit appeared and became prominently phosphorylated in the phosphotyrosine immunoblotting. In addition, after insulin injection a broad phosphotyrosyl protein migrating between 165 and 185 $k D$, consistent with IRS-1 the endogenous substrate of the insulin receptor kinase was also detectable. Similar results were obtained in muscle. There was no increase in intensity of the 110 and $120 \mathrm{kD}$ bands by insulin injection.

Anti-IRS-1 antibody reacted on immunoblots with a single broad protein band in extracts from $\mathrm{CHO} / \mathrm{HIRC}$ cells and normal liver and skeletal muscle from rats (Fig. $1 B$ ). The apparent molecular mass of IRS-1 was between 165 and $185 \mathrm{kD}$ in CHO cells, between 150 and $165 \mathrm{kD}$ in liver and between 165 and $175 \mathrm{kD}$ in muscle. A similar molecular weight heterogeneity of IRS-1 was also observed in mouse tissues (data not shown). The broad nature of the IRS- 1 band in CHO cells and liver resembles the broad bands observed with anti-phosphotyrosine antibodies.

To quantitate whether IRS-1 is the only protein in the pp 185 band, liver and muscle extracts from insulin-stimulated rats were subjected to multiple rounds of depletion of IRS-1 with anti-IRS-1 antibody ( $\alpha \mathrm{p} 80)$. Immunoprecipitated proteins were then solubilized in Laemmli sample buffer, reduced with $100 \mathrm{mM}$ DTT, separated by $6 \%$ SDS-PAGE, transferred to nitrocellulose, and immunoblotted with anti-phosphotyrosine antibody and $\alpha \mathrm{p} 80$ antibody. The results show that four rounds of depletion of IRS- 1 protein in liver using $\alpha \mathrm{p} 80$ antibody removes over $98 \%$ of the IRS-1/pp185 protein as detected by anti-IRS-1 and anti-phosphotyrosine antibodies. The results were very similar in muscle; after four rounds of depletion with $\alpha \mathrm{p} 80$, the band corresponding to pp 185 represented only $0.4 \%$ of the original pp 185 phosphoprotein. Fur- thermore, in both liver and muscle extracts, the depletion of IRS- 1 as measured by anti-phosphotyrosine and $\alpha$ p 80 antibodies after each round of precipitation was almost identical. These data indicate that, at least in liver and muscle, IRS- 1 and pp185 are the same protein. If there are additional phosphotyrosine-containing proteins in the pp185 band they represent $<2 \%$ and $0.5 \%$ of liver and muscle pp 185 , respectively.

Animal characteristics. Table I summarizes the body weight, plasma glucose, and serum insulin levels of animals in all studies. Rats starved for 24,48 , and $72 \mathrm{~h}$ showed a progress decrease in body weight from 172 to $139 \mathrm{~g}$ and a parallel decrease in the levels of plasma glucose and serum insulin. Rats rendered diabetic by streptozotocin were markedly hyperglycemic and hypoinsulinemic, and gained little or no weight over the $7 \mathrm{~d}$. Plasma glucose and serum insulin levels, as well as the body weights, were markedly increased in the ob/ob mouse compared to the ob/+ control mice.

Effect of fasting on insulin receptors and IRS-1 phosphorylation in liver and muscle. Insulin binding to plasma membranes from liver and muscle was higher in fasted than in fed rats. In liver, the percent of labeled insulin bound increased by $21.5 \%, 37.7 \%$, and $61 \%$ at 24,48 , and $72 \mathrm{~h}$, respectively (Fig. 2 $C)$. In muscle the time course and magnitude of change was similar (Fig. $3 \mathrm{C}$ ). Previous studies have shown that this increase in binding is due to an increase in binding capacity rather than to an increase in binding affinity in these tissues $(4,32)$.

During the $3 \mathrm{~d}$ of fasting there were no alterations in the constitutively phosphotyrosine-containing protein pp120 in liver (Fig. $2 A$ ). By comparison insulin-stimulated phosphorylation of the $95 \mathrm{kD} \beta$ subunit of the insulin receptor increased. Scanning densitometry revealed an increase of $17 \%(P<0.05)$, $56 \%(P<0.05)$, and $24 \%(P<0.05)$ at 24,48 , and $72 \mathrm{~h}$ of fasting, respectively (Fig. $2 C$ ). When the data were corrected for the amount of insulin binding activity, there was no change in receptor phosphorylation per receptor in liver of rats fasted for 24 and $48 \mathrm{~h}$, and a $23 \%$ decrease $(P<0.05)$ after $72 \mathrm{~h}$ of fasting.

Insulin-stimulated phosphorylation of IRS-1 increased during the $3 \mathrm{~d}$ of fasting (Fig. $2 \mathrm{~A}$ ). Quantitation of these data and those of similar experiments revealed a stepwise increase by $32.5 \%(P<0.05), 71.7 \%(P<0.001)$, and finally $94.7 \%(P$ $<0.01$ ) each day during the fast (Fig. $2 D$ ). After immunoprecipitation with $\alpha \mathrm{p} 80$ and immunoblotting with anti-phosphotyrosine antibody there was also a clear increase in IRS-1 phos-

Table I. Characteristics of Rats and Mice Studied

\begin{tabular}{lrccrc}
\hline \multicolumn{1}{c}{ Groups } & $n$ & Body weight & Plasma glucose & \multicolumn{1}{c}{ Serum insulin } \\
\hline & & $g$ & $m g / d l$ & $\mu U / m l$ \\
Fed & 8 & $172 \pm 3$ & $141 \pm 5(6)$ & $23 \pm 3(6)$ \\
Fasted $24 \mathrm{~h}$ & 8 & $157 \pm 4$ & $114 \pm 2(6)$ & $15 \pm 1(5)$ \\
$\quad 48 \mathrm{~h}$ & 8 & $148 \pm 3$ & $102 \pm 1(6)$ & $11 \pm 1(5)$ \\
$\quad 72 \mathrm{~h}$ & 8 & $139 \pm 3$ & $94 \pm 3(6)$ & $7 \pm 2(6)$ \\
Control & 18 & $171 \pm 3$ & $108 \pm 5(18)$ & $18 \pm 2(6)$ \\
STZ diabetes & 18 & $139 \pm 3$ & $418 \pm 17(18)$ & $11 \pm 2(6)$ \\
ob/+ & 8 & $18.2 \pm 0.4$ & $117 \pm 17(4)$ & $39 \pm 7(4)$ \\
ob/ob & 8 & $34.2 \pm 0.4$ & $390 \pm 35(4)$ & $388 \pm 89(4)$
\end{tabular}

The data are represented as the mean \pm SEM. 

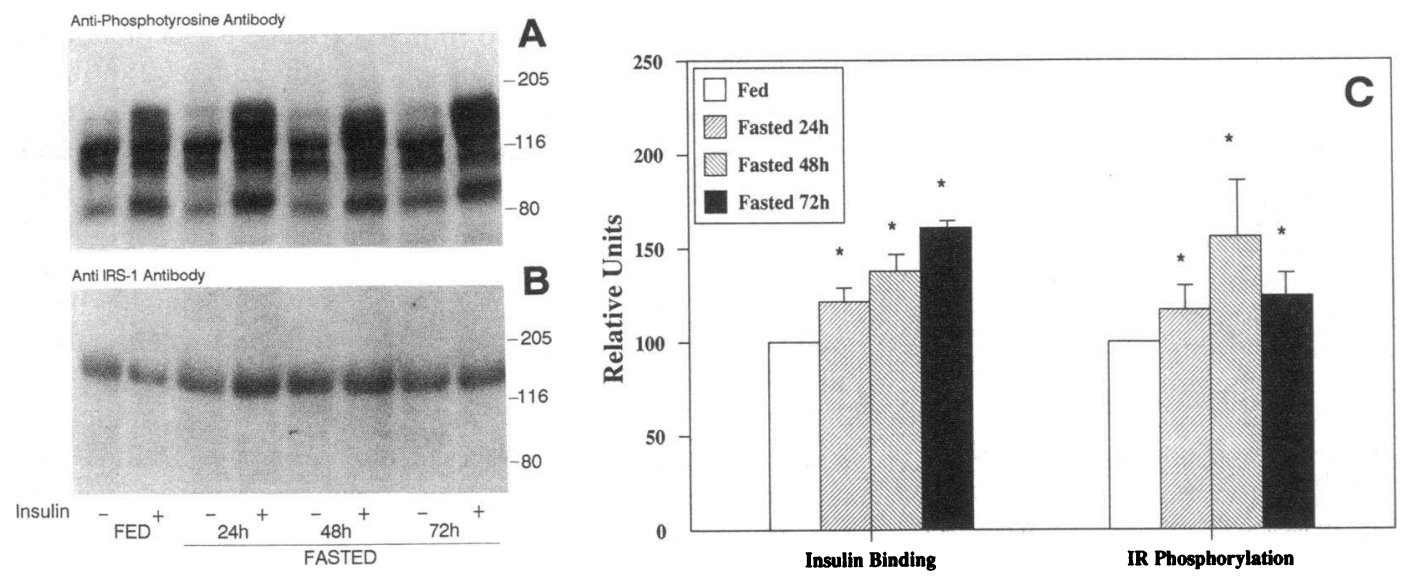

Figure 2. (A)

Insulin-stimulated tyrosine phosphorylation in intact liver from fed and fasted rats. The proteins from the liver were isolated as described in Methods and processed as described in the legend to Fig. $1 \mathrm{~A}$. Extracts from rats injected with normal saline are in lanes marked “-" and with $10^{-5} \mathrm{M}$ insulin in lanes marked “+”. (B) IRS-1 levels in liver from fed and
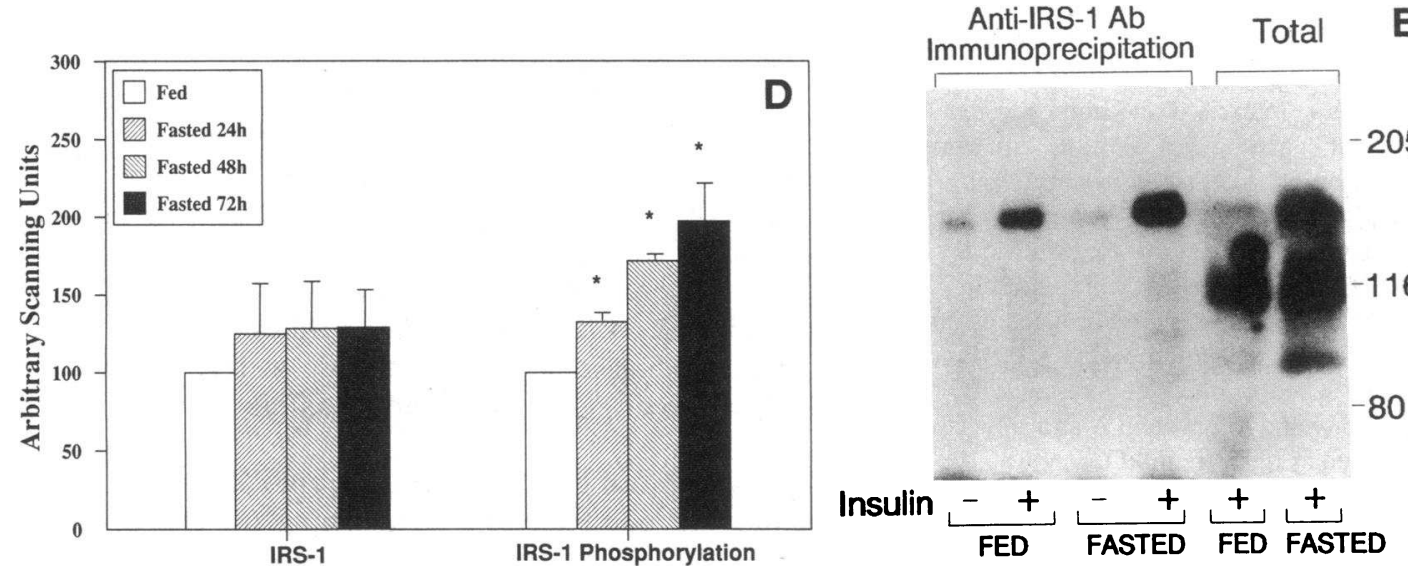

E fasted rats. Aliquots from the same samples were also resolved on $6 \%$ SDS-polyacrylamide gels, transferred to nitrocellulose, and detected with anti-peptide 80 antibody instead of anti-phosphotyrosine antibody. ( $C$ ) Effect of fasting on insulin binding and insulin receptor phosphorylation in liver of rats. Insulin binding was determined as described in Methods and are expressed as per-

centage of control fed values. The values are derived from four separate experiments. Insulin receptor phosphorylation in vivo was determined by scanning densitometry of four separate experiments. The values are represented as the mean \pm SEM. *Differences from control (fed) at $P<$ 0.05. $(D)$ Effect of fasting on IRS-1 levels and phosphorylation in liver of rats. Scanning densitometry of four to six experiments. The values are represented as the mean \pm SEM. *Differences from control (fed) at $P<0.05$. (E) Insulin-stimulated tyrosine phosphorylation of IRS-1 in intact liver of fed and 72-h fasted rats. Samples from fed (lanes 1 and 2) and 72-h fasted rats (lanes 3 and 4 ) were extracted with homogenization buffer B and immunoprecipitated with anti-peptide 80 antibody. Samples from lanes 5 and 6 are aliquots of total extracts from the same sources of samples from lanes 2 and 4, respectively. All samples were resolved on 6\% SDS-PAGE, transferred to nitrocellulose, and detected with antiphosphotyrosine antibody. $M_{\mathrm{r}}$ bands given at right in $A, B$, and $E$ are in $\mathrm{kD}$.

phorylation after $3 \mathrm{~d}$ of fasting (Fig. $2 E$ ). Using the specific anti-peptide antibody ( $\alpha$ p80) against IRS-1, there was a slight but not statistically significant increase in the level of IRS-1 in liver during the fasting period. Acute insulin stimulation had no effect on IRS-1 protein levels. This was confirmed by scanning densitometry (Fig. $2 \mathrm{D}$ ).

The effect of starvation on phosphotyrosyl proteins in muscle was similar to that in liver (Fig. $3 A$ ). By comparison of the lanes after insulin stimulation, there was an increase in the $\beta$ subunit phosphorylation of $26.2 \%(P<0.05)$ at $24 \mathrm{~h}, 41.9 \%$ at $48 \mathrm{~h}$, and $36.2 \%(P<0.05)$ at $72 \mathrm{~h}$ of fasting (Fig. $3 C)$. When the data were corrected for the amount of insulin binding, phosphorylation per receptor in muscle during the $3 \mathrm{~d}$ of fasting did not change significantly.

Fig. $3 A$ also shows an increase in insulin-stimulated IRS-1 phosphorylation in skeletal muscle during the $3 \mathrm{~d}$ of fasting. The increase was almost maximal at $24 \mathrm{~h}(84.2 \%, P<0.05)$ and then only increased slightly to $104 \%(P<0.025)$ over the next $2 \mathrm{~d}$ (Fig. $3 \mathrm{D}$ ). The increase in the phosphorylation of IRS-1 during the fasting was also demonstrated in an experiment in which the samples from muscle were immunoprecipitated with anti-IRS- 1 antibody and analyzed by immunoblotting with anti-phosphotyrosine antibody (Fig. $3 E$ ). By con- trast, there was a significant decrease in the level of IRS-1 protein in muscle during starvation analyzed by immunoblotting with $\alpha \mathrm{p} 80$ antibody with the lowest levels after $72 \mathrm{~h}$ of fasting (Fig. 3, $B$ and $D$ ). The decrease was by $29.7 \pm 10.5 \%(P$ $<0.05), 30.2 \pm 13.4 \%(P<0.05)$, and $46.5 \pm 9.9 \%(P<0.005)$ after 24,48 , and $72 \mathrm{~h}$ fasting, respectively (Fig. $3 \mathrm{D}$ ).

Effect of STZ diabetes on insulin receptor and IRS-1 phosphorylation in liver and muscle. The binding of ${ }^{125} \mathrm{I}$-insulin to plasma membranes from liver and muscle was higher in STZ diabetes as compared with controls (Fig. $4 \mathrm{C}$ ). According to previous studies, this increase in binding in liver (21) and muscle (3) in STZ diabetes is primarily due to increased binding capacity rather than to a change in binding affinity. After insulin stimulation, the extent of insulin receptor autophosphorylation was similar in liver of control and diabetic rats (Fig. $4 A$ ). In that insulin binding increases in diabetic rats, when the data are normalized for receptor binding activity, there was a decrease in receptor phosphorylation in liver of STZ diabetes by $43.5 \%(P<0.01)$. Similarly, the phosphorylation of IRS-1 also showed no significant increase in liver of diabetic rats after insulin stimulation (Fig. 4, $A$ and $D$ ). The same result was observed in two separate experiments where the samples from liver were immunoprecipitated with antibody $\alpha$ p80 and ana- 

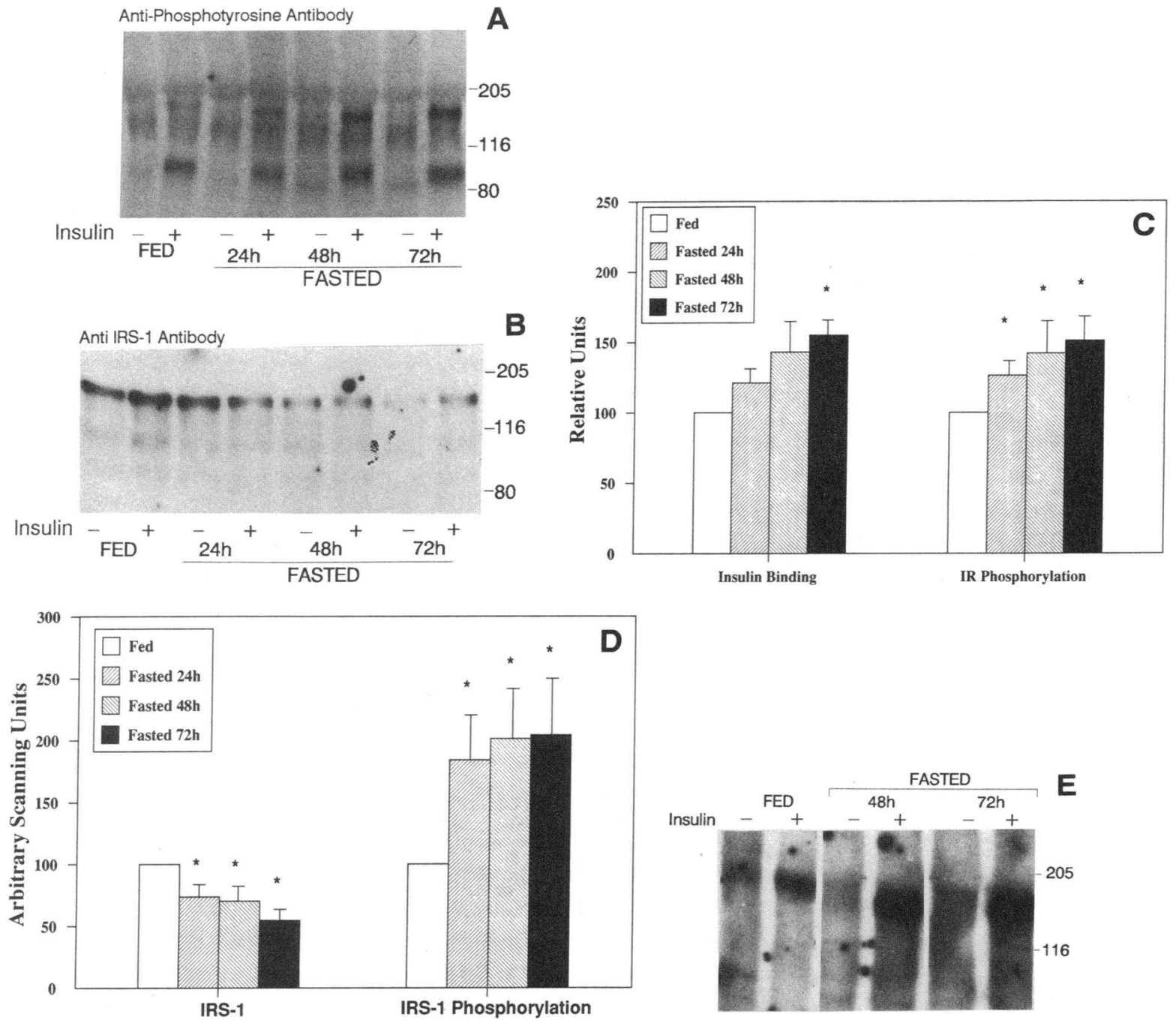

Figure 3. $(A)$ Insulin-stimulated tyrosine phosphorylation in intact muscle from fed and fasted rats. The proteins from the skeletal muscle were isolated as described in Methods and processed as described in the legend to Fig. 1. Extracts from rats injected with normal saline are in lanes marked "-" and with $10^{-5} \mathrm{M}$ insulin in lanes marked "+". $(B)$ IRS-1 levels in muscle from fed and fasted rats. Aliquots from the same samples were also resolved on $6 \%$ SDS-polyacrylamide gels, transferred to nitrocellulose, and detected with anti-peptide 80 antibody. ( $C$ ) Effect of fasting on insulin binding and insulin receptor phosphorylation in muscle of rats. Insulin binding was determined as described in Methods and is expressed as percent of control values. The values are derived from four separate experiments. Insulin receptor phosphorylation in vivo was determined by scanning densitometry of five separate experiments. The values are represented as the mean \pm SEM. ${ }^{*}$ Differences from control (fed) at $P<0.05$. (D) Effect of fasting on IRS-1 levels and phosphorylation in muscle of rats. Scanning densitometry of six to eight experiments. The values are represented as the mean \pm SEM. *Differences from control (fed) at $P<0.05$. ( $E$ ) Insulin-stimulated tyrosine phosphorylation of IRS-1 in intact skeletal muscle of fed and fasted rats. Samples from fed (lanes 1 and 2), 48-h fasted (lanes 3 and 4), and 72-h fasted rats (lanes 5 and 6) were extracted as described in Methods, immunoprecipitated with anti-peptide 80 antibody and immunoblotted with anti-phosphotyrosine antibody. $M_{\mathrm{r}}$ bands given at right in $A, B$, and $E$ are in $\mathrm{kD}$.

lyzed by immunoblotting with anti-phosphotyrosine antibody (Fig. $5 E$ ). The levels of IRS-1 protein were almost $30 \%$ higher in liver of diabetic rats as analyzed by immunoblotting with $\alpha$ p80 antibodies (Fig. $4, B$ and $D$ ).

Fig. 5, $A$ and $B$ show immunoblotting of muscle samples from controls and diabetic rats analyzed with anti-phosphotyrosine and anti-IRS-1, respectively. 2 min after portal infusion of insulin, receptor autophosphorylation was $43 \%$ higher in diabetic muscles compared with controls (Fig. $5 \mathrm{C}$ ). Again, when the data were corrected for the amount of insulin binding activity, there is a $29 \%(P<0.05)$ decrease in receptor phosphorylation. The phosphorylation of IRS-1 also increased in muscle from diabetic rats by $106 \pm 38 \%$. The extent of the increase in phosphorylation was higher in IRS-1 than in insulin receptor $(106 \pm 38 \%$ vs. $43 \pm 19 \%)$. The muscle extracts that were immunoprecipitated with antibodies against IRS-1 and immunoblotted with anti-phosphotyrosine antibody also showed an increase in IRS-1 phosphorylation in samples from diabetic animals (Fig. $5 E$ ). The levels of IRS-1 analyzed by direct immunoblotting with $\alpha \mathrm{p} 80$ antibodies showed a small ( $18 \%)$ but significant $(P<0.05)$ decrease in muscle from STZ diabetic rats (Fig. 5, $B$ and $D$ ). There was no change in the level of pp120 in extracts of muscle from diabetic rats compared with controls, either before or after insulin stimulation. 

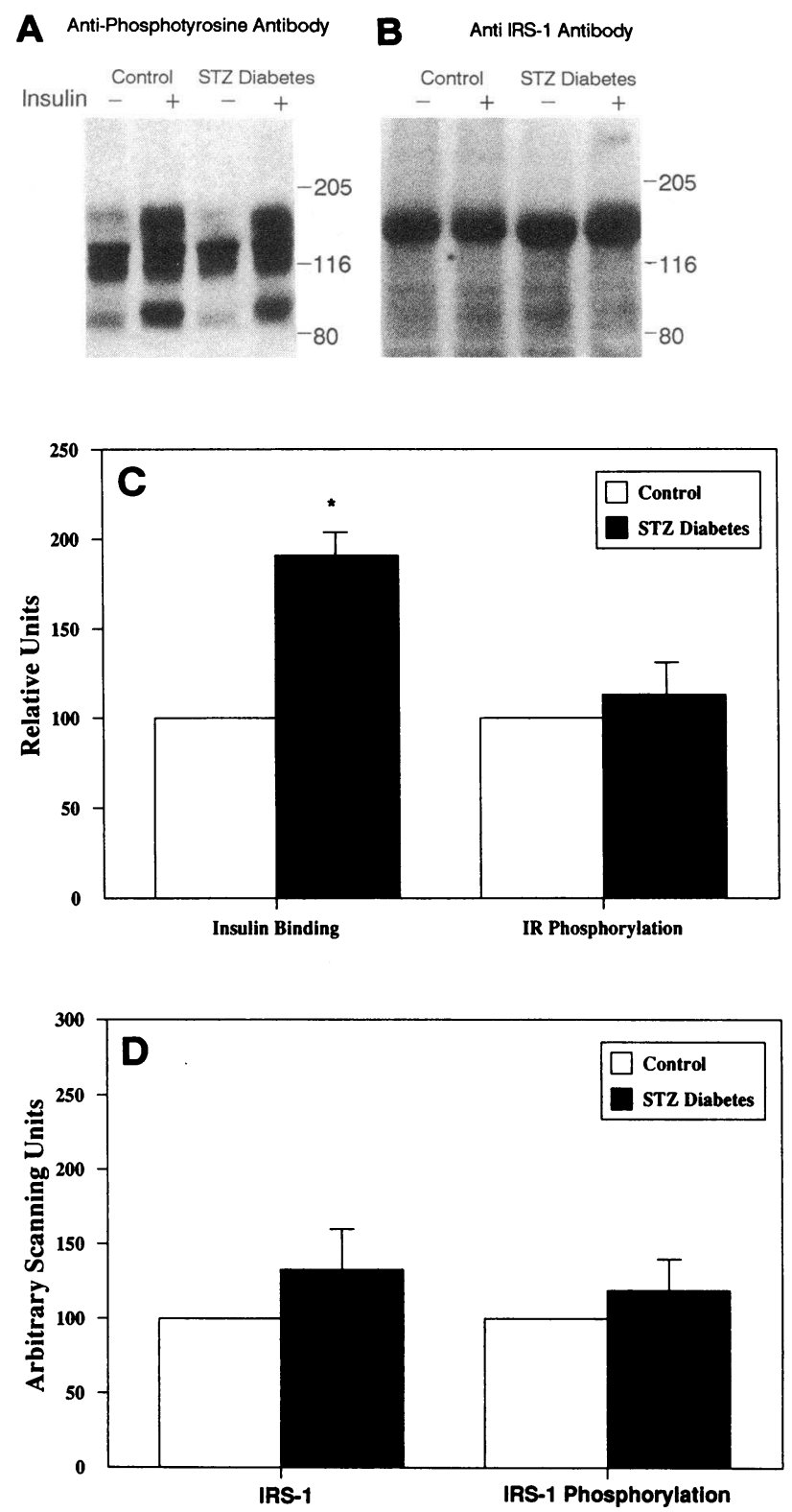

Figure 4. (A) Insulin-stimulated tyrosine phosphorylation in intact liver from control and STZ diabetic rats. The proteins from the liver were isolated as described in Methods and processed as described in the legend to Fig. 1. Extracts from rats injected with normal saline are in lanes marked "-" and with $10^{-5} \mathrm{M}$ insulin in lanes marked "+". (B) IRS-1 levels in liver from control and STZ diabetic rats. Aliquots from the same samples were also resolved on 6\% SDS-polyacrylamide gels, transferred to nitrocellulose and detected with antipeptide 80 antibody instead of anti-phosphotyrosine antibody. $M_{\mathrm{r}}$ bands given at right are in $\mathrm{kD}$. (C) Effect of STZ diabetes on insulin binding and insulin receptor phosphorylation in liver of rats. Insulin binding was determined as described in Methods and is expressed as percentage of control. The values are derived from four separate experiments. Insulin receptor phosphorylation in vivo was determined by scanning densitometry of six separate experiments. The values are represented as the mean \pm SEM. ${ }^{*}$ Differences from control at $P$ $<0.05$. (D) Effect of STZ diabetes on IRS-1 levels and phosphorylation in liver of rats. Scanning densitometry of six experiments (IRS-1 phosphorylation) and 12 experiments (IRS-1 protein levels). The values are represented as the mean \pm SEM. *Differences from control at $P<0.05$.
Insulin receptor and IRS-1 phosphorylation in liver and muscle of ob/ob mice. There was a decrease in binding of insulin to plasma membranes from ob/ob mouse liver and skeletal muscle (Fig. $6 \mathrm{C}$ ). This decrease in insulin binding has been attributed to a decreased number of receptors rather than to a change in the affinity of insulin for its receptor $(28,33)$.

As in the rat livers, the major, constitutively phosphotyrosine-containing protein in mouse liver was a closely spaced doublet $M_{\mathrm{r}} 120 \mathrm{kD}$ (Fig. $7 A$ ). After insulin infusion, the $95-\mathrm{kD}$ insulin receptor $\beta$ subunit became phosphorylated. The extent of receptor autophosphorylation was only slightly decreased in the ob/ob diabetic mice compared with ob/ + controls (Fig. 6, $A$ and $C$ ). Indeed, when corrected for insulin binding, there was a modest increase in receptor autophosphorylation in liver of ob/ob mice. The phosphorylation of IRS-1 band in liver of $\mathrm{ob} / \mathrm{ob}$ mice was markedly reduced when compared to ob/+ controls (Fig. 6, $A$ and $D$ ). In some experiments, phosphorylated IRS-1 appeared as a closely spaced doublet in the liver extracts of ob/+ mice, whereas in samples from the ob/ob mice the upper band almost completely disappeared. The levels of IRS-1 protein were also decreased by $34 \%(P<0.025)$ in livers of ob/ob mouse compared to ob/+ controls (Fig. 6, $B$ and $D$ ).

In muscle, the level of insulin-stimulated phosphorylation of the insulin receptor $\beta$ subunit was reduced by $40 \%$ in ob/ob mouse as compared to their lean controls $(P<0.05)$ (Fig. 7, $A$ and $C$ ). When these data were corrected for insulin binding, there was no change in insulin receptor phosphorylation in skeletal muscle of ob/ob mouse. The extent of phosphorylation of IRS-1 after insulin stimulation was decreased about $50 \%$ by scanning densitometry in ob/ob mouse compared to ob $/+$ controls $(P<0.01)$ (Fig. $7 D)$. In samples previously immunoprecipitated with $\alpha \mathrm{p} 80$ and immunoblotted with antiphosphotyrosine antibody also showed a major decrease in IRS-1 phosphorylation in liver and muscle of ob/ob mice (Figs. $6 E$ and $7 E$ ). In the immunoblotting of muscle extracts of mouse with antibodies to IRS-1, the levels of IRS-1 protein appeared similar in ob/+ controls and ob/ob mouse (Fig. 7, B and $D$ ).

\section{Discussion}

Whereas the insulin receptor has been extensively characterized from a biochemical perspective, the exact molecular events linking the receptor tyrosine kinase to its cellular action are poorly understood. In most, if not all cells, insulin stimulates tyrosine phosphorylation of a cytoplasmic protein of relative molecular mass between 165 and $185 \mathrm{kD}(12-19)$. This protein has been recently purified, cloned, and termed IRS-1 (20), and shown to be a direct substrate of the insulin receptor in vivo and in vitro. Direct phosphorylation of IRS-1 by the activated insulin receptor can be demonstrated in vitro by incubation of baculovirus-produced IRS-1 with purified insulin receptor (Sun et al., manuscript submitted for publication). The phosphorylation of IRS-1 is decreased in cells expressing a mutant insulin receptor, and the decrease correlates with defective insulin signaling (29). This close correlation of phosphorylation and insulin action and the novel structure of this protein with multiple tyrosine phosphorylation sites in Tyr-Met-XxxMet motif capable of interacting bearing SH2 domains (20) 
A Anti-Phosphotyrosine Antibody

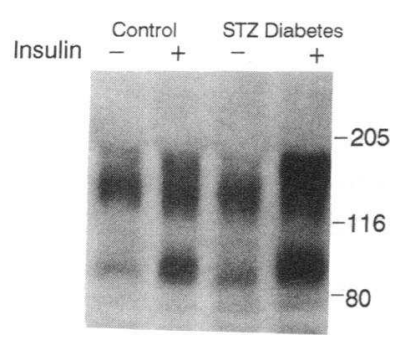

B Anti IRS-1 Antibody

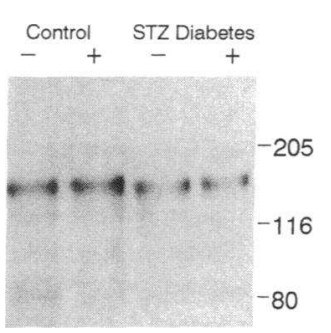

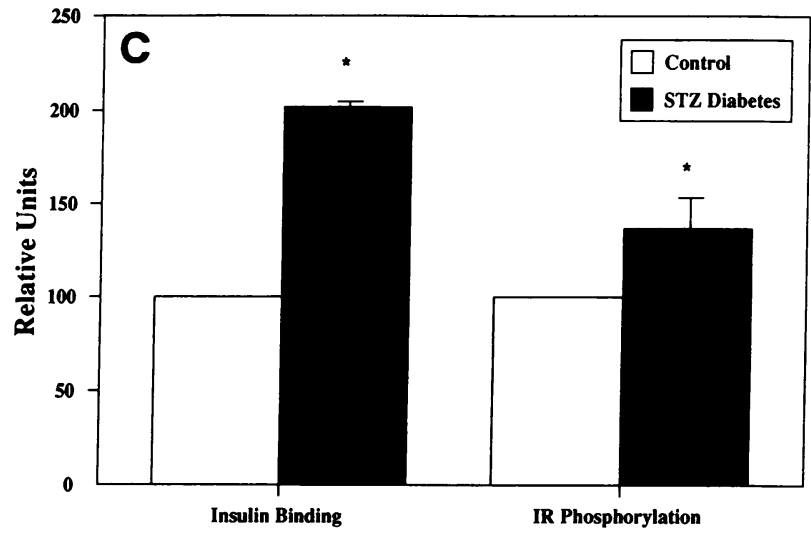

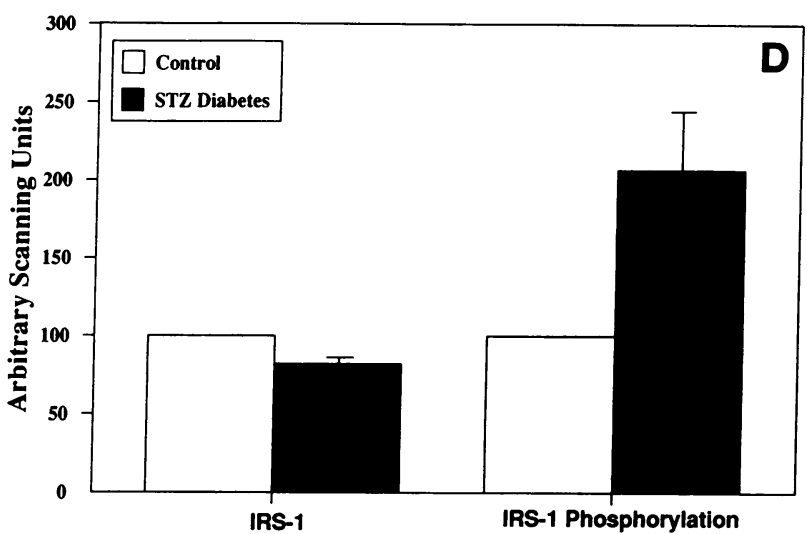

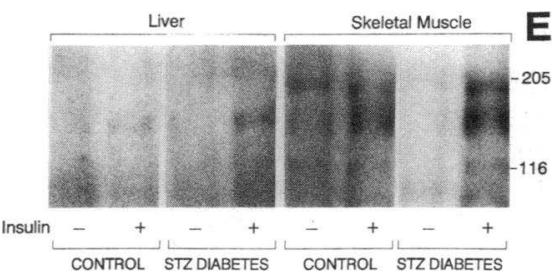

Figure 5. (A) Insulin-stimulated tyrosine phosphorylation in intact skeletal muscle from control and STZ diabetic rats. The proteins from the liver were isolated as described in Methods and processed as described in the legend to Fig. 1. Lanes marked "-" represent rats injected with normal saline and lanes marked "+" represent rats injected with $10^{-5} \mathrm{M}$ insulin. (B) IRS-1 levels in muscle from control and STZ diabetic rats. Aliquots from the same samples were also resolved on $6 \%$ SDS-polyacrylamide gels, transferred to nitrocellulose, and detected with anti-peptide 80 antibody. $(C)$ Effect of STZ diabetes on insulin binding and insulin receptor phosphorylation in muscle of rats. Insulin binding was determined as described in Methods and is expressed as percentage of control. The values are derived from four separate experiments. Insulin receptor phosphorylation in vivo was determined by scanning densitometry of eight separate experiments. The values are represented as the mean \pm SEM. ${ }^{*}$ Differences from control at $P<0.05$. (D) Effect STZ diabetes on IRS-1 levels and phosphorylation in muscle of rats. Scanning densitometry of eight experiments for IRS-1 phosphorylation and 16 experiments for IRS-1 protein levels. The values are represented as the mean \pm SEM. ${ }^{*}$ Differences from control at $P<0.05$. ( $E$ ) Insulin-stimulated tyrosine phosphorylation in intact liver and muscle from control and STZ diabetes. The proteins from liver and muscle were isolated as described in Methods, immunoprecipitated with anti-peptide 80 antibody and immunoblotted with anti-phosphotyrosine antibody. $M_{\mathrm{r}}$ bands given at right in $A, B$, and $E$ are in $\mathrm{kD}$.

suggest an important role in insulin action. Although decreased insulin receptor kinase activity has been reported in various insulin-resistant states, the expression and phosphorylation of IRS-1 has not been examined in insulin-resistant states.

In the present study we have evaluated the role of insulin receptor kinase activation and receptor substrate tyrosine phosphorylation in the insulin signal transduction process in tissues of intact animals using anti-phosphotyrosine and antiIRS-1 antibodies $(25,34)$. In most prior animal studies of insulin receptor function, the receptors were first partially purified, and then in vitro kinase assays were performed using exogenous phosphoacceptor substrates $(21,35)$. Although informative, the latter approach is susceptible to biochemical artifacts resulting from cell homogenization and receptor purification procedures, e.g., proteolysis (36) and/or dephosphorylation of the receptor by contaminating phosphoprotein phosphatases (37), as well as removal of the receptor from the plasma membrane where interactions with other cellular components may influence receptor activity (38). Furthermore, differences in receptor kinase activity may be manifest in vitro with certain specific phosphoacceptor substrate proteins, but not with others (39). The method employed in this study is not subject to such complications and permits a direct assessment of insulin-stimulated tyrosine phosphorylation of the major endogenous substrate of potential physiological significance in small samples from diverse tissues type (25). We have evaluated in vivo insulin stimulation tyrosine phosphorylation in three situations of insulin resistance: fasting, insulinopenic diabetes, and the obesity-associated insulin resistance. A summary of the results is presented in Table II.

Prolonged fasting in rats is characterized by insulin deficiency and insulin resistance $(4,40)$. In vivo both peripheral and hepatic insulin resistance on glucose metabolism have been observed (41), despite an increase in insulin receptor number (32). The mechanism by which insulin resistance occurs appears to differ from tissue to tissue. Insulin receptors solubilized and partially purified from 72-h fasting rats show a decrease insulin-stimulated autophosphorylation and exoge- 

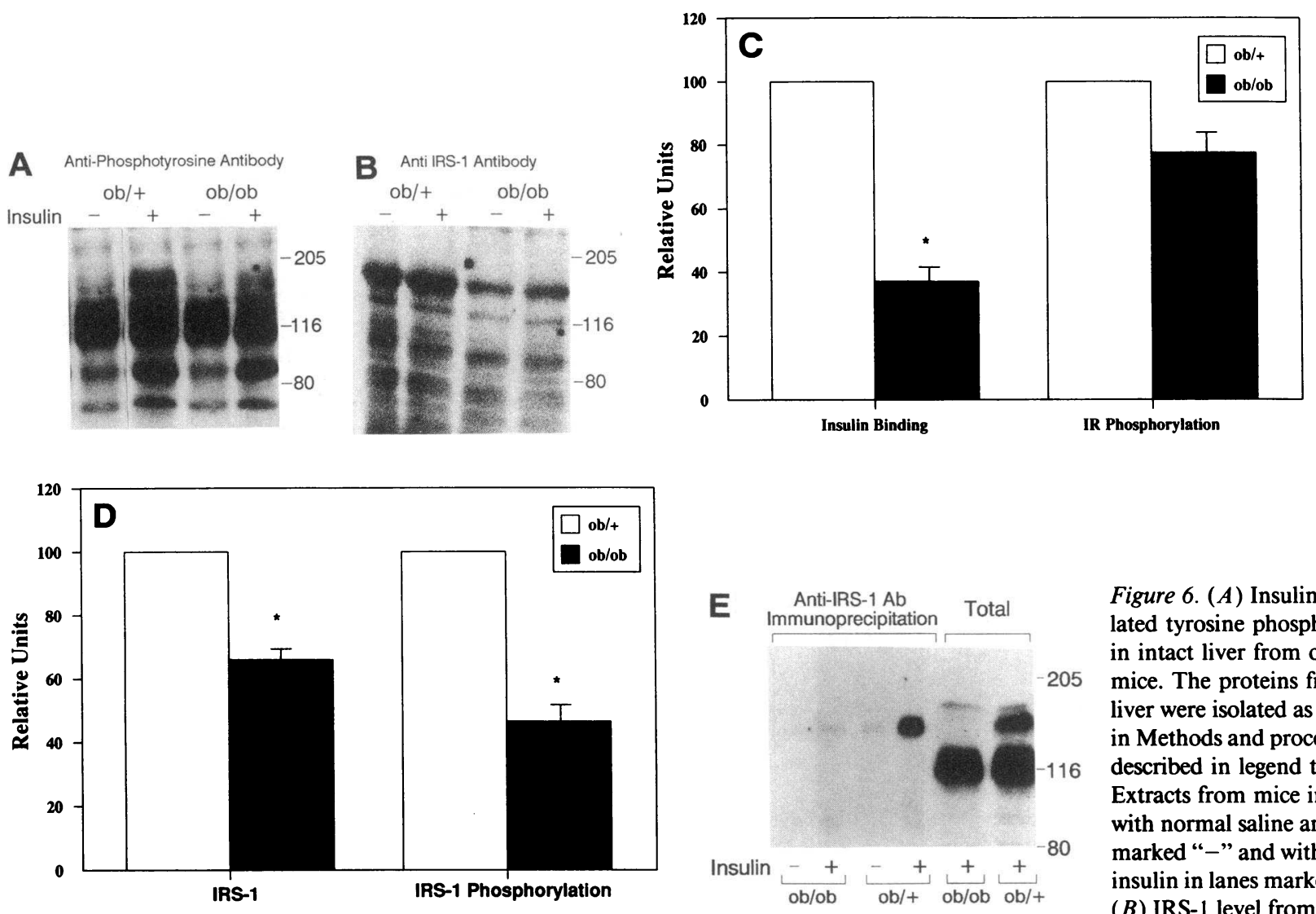

Figure 6. (A) Insulin-stimu- . lated tyrosine phosphorylation in intact liver from ob/ob mice. The proteins from the liver were isolated as described in Methods and processed as described in legend to Fig. 1. Extracts from mice injected with normal saline are in lanes marked "-" and with $10^{-5} \mathrm{M}$ insulin in lanes marked "+". (B) IRS-1 level from ob/ob

mice. Aliquots from the same samples were also resolved on $6 \%$ SDS-polyacrylamide gels, transferred to nitrocellulose, and detected with antipeptide 80 antibody. $(C)$ Insulin binding and insulin receptor phosphorylation in liver of ob/ob mice. Insulin binding was determined as described in Methods and is expressed as percentage of control $(\mathrm{ob} /+)$. The values are derived from four separate experiments. Insulin receptor phosphorylation in vivo was determined by scanning densitometry of four separate experiments. The values are represented as the mean \pm SEM. ${ }^{*}$ Differences from control $(\mathrm{ob} /+)$ at $P<0.05$. (D) IRS-1 levels and phosphorylation in liver of ob/ob mice. Scanning densitometry of four experiments for IRS-1 phosphorylation and eight experiments for IRS-1 protein levels. The values are represented as the mean \pm SEM. ${ }^{*}$ Differences from control $(\mathrm{ob} /+)$ at $P<0.05$. (E) Insulin stimulation tyrosine phosphorylation in intact liver from ob/ob mice. Samples from ob/ob (lanes $l$ and 2 ) and ob $/+$ (lanes 3 and 4 ) were extracted as described in Methods, and immunoprecipitated with anti-peptide 80 antibody. Samples from lanes 5 and 6 are aliquots of total extracts from the same sources of samples from lanes 2 and 4 , respectively. All samples were resolved on 6\% SDS-PAGE, transferred to nitrocellulose and detected with anti-phosphotyrosine antibody. $M_{\mathrm{r}}$ bands given at right in $A, B$, and $E$ are in kD.

nous tyrosine kinase activation in liver, but not in muscle (4). Our results (normalized by total protein) showed an increase of $25 \%$ in insulin receptor autophosphorylation in liver and of $40 \%$ in muscle after $72 \mathrm{~h}$ of fasting. However, if we normalize the data for insulin binding, they are in accordance with previous data that show a reduced receptor autophosphorylation (per receptor) in liver, but not in muscle after $72 \mathrm{~h}$ of fasting. By contrast, the in vivo phosphorylation of IRS- 1 increases twofold in both liver and muscle after $72 \mathrm{~h}$ of fasting.

It is interesting that IRS-1 phosphorylation increases in both liver and muscle, whereas the level of IRS-1 protein as determined by direct immunoblotting increases in liver but decreases in muscle during fasting (Table II). The phosphorylation of IRS-1, the endogenous substrate of the insulin receptor kinase, which has been implicated in signal transmission (29), is increased and parallels the increase in total receptor phosphorylation. The discrepancies between the actual quantitative magnitude of increase in $\beta$ subunit phosphorylation and IRS-1 phosphorylation suggest that there may be amplification of the insulin-stimulated signal (i.e., tyrosine kinase activity) between $\beta$ subunit autophosphorylation and the phosphorylation of IRS-1.

This increase in IRS-1 (and total receptor) phosphorylation with fasting occurs despite a state of decreased insulin responsiveness in both liver and peripheral tissues of fasted animals (40). The fact that euglycemic clamp studies show decreased insulin-stimulated glucose uptake in muscle in vivo with fasting suggests that tissue or circulating factors such as fatty acids, ketones, counterregulatory hormones, and acidosis may antagonize the stimulatory action of insulin on glucose transport in muscle as previously discussed (41). It is possible that the increase in IRS-1 phosphorylation in liver and muscle during the 3-d fast could be a response to the impairment of insulin action.

Impaired insulin receptor kinase activation may play a role in the insulin resistance of insulinopenic diabetes. There is decreased kinase activity in receptors solubilized from muscle (3) and liver $(21,34)$ of rats rendered diabetic with streptozotocin; however, other studies have reported an increase or no change in kinase activity in solubilized receptors from liver (42) and 

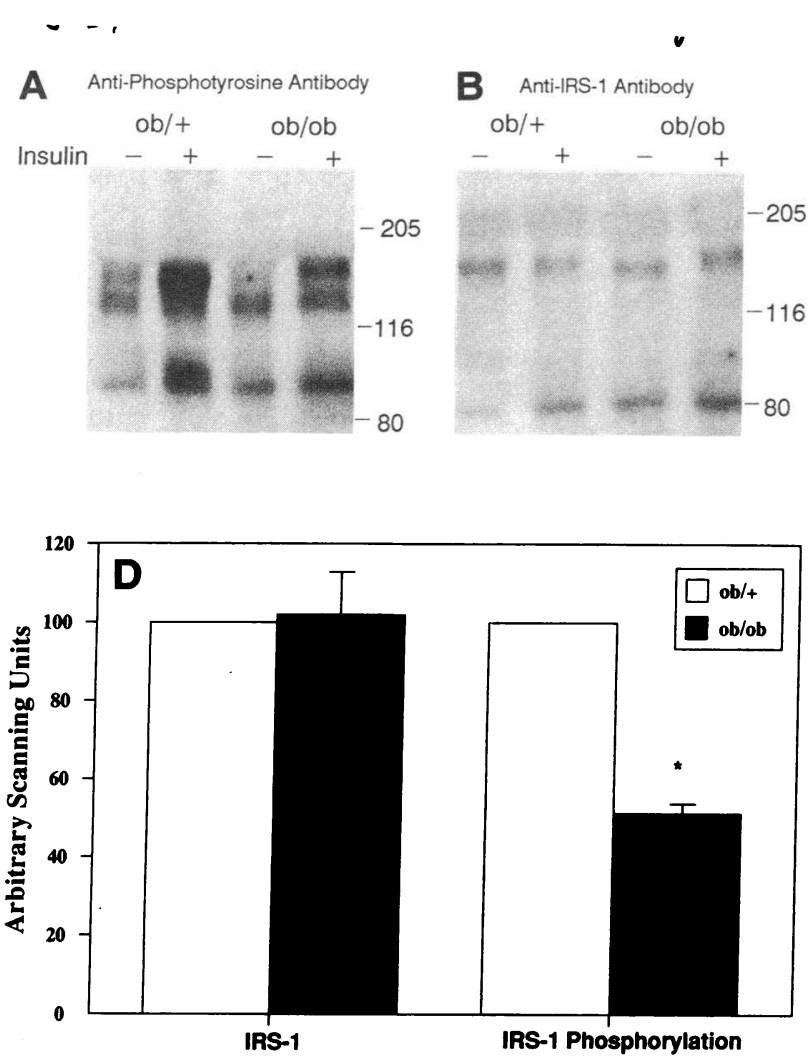
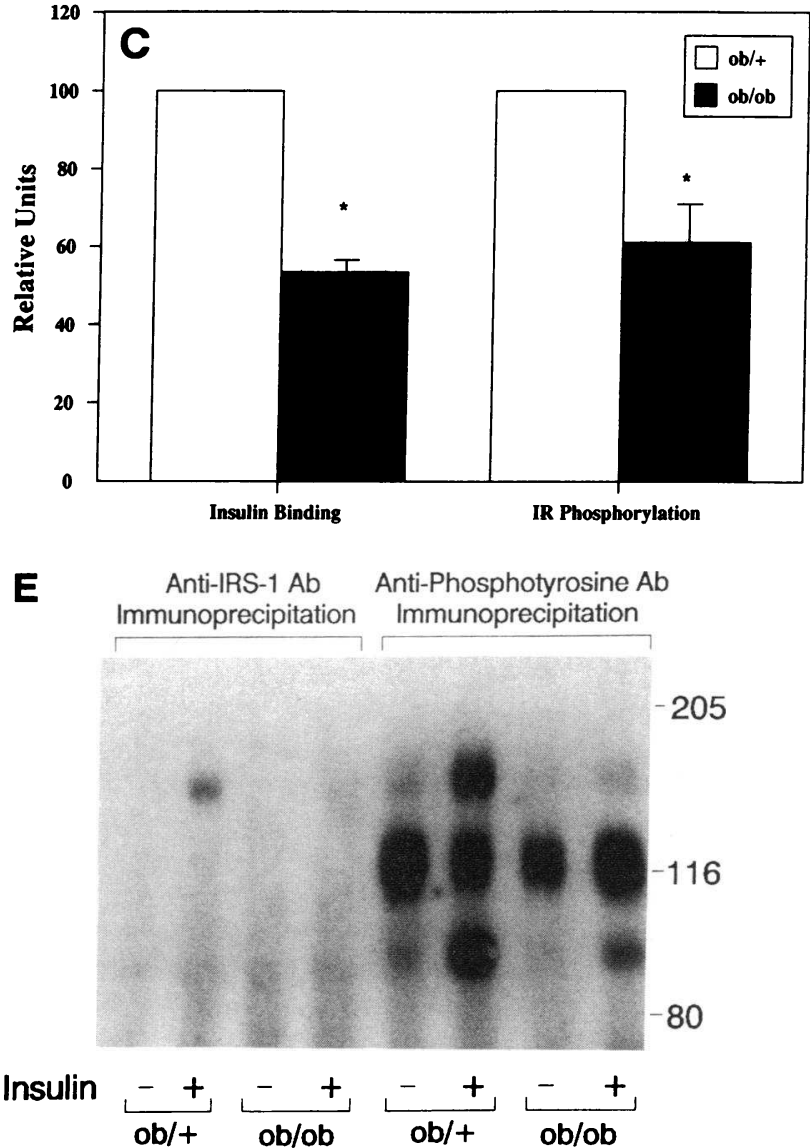

Figure 7. (A) Insulin-stimulated tyrosine phosphorylation in intact skeletal muscle of ob/ob mice. The proteins from hindlimb muscle were isolated as described in Methods and processed as described in the legend to Fig. 1. Data are shown as in Fig. $6 \mathrm{~A}$. (B) IRS-1 level from ob/ob mice. Aliquots from the same samples were also resolved on 6\% SDS-PAGE, transferred to nitrocellulose, and detected with anti-peptide 80 antibody. $(C)$ Insulin binding and insulin receptor phosphorylation in skeletal muscle of ob/ob mice. Insulin binding was determined as described in Methods and is expressed as percentage of control $(\mathrm{ob} /+)$. The values for binding and insulin receptor phosphorylation are from four separate experiments and are represented as the mean \pm SEM. ${ }^{*}$ Differences from control $(\mathrm{ob} /+)$ at $P<0.05$. ( $D$ ) IRS-1 levels and phosphorylation in skeletal muscle of ob/ob mice. The values for IRS-1 levels and phosphorylation are represented as the mean \pm SEM of scanning densitometry of four experiments. ${ }^{*}$ Differences from control $(\mathrm{ob} /+)$ at $P<0.05$. $(E)$ Insulin stimulation tyrosine phosphorylation in intact skeletal muscle of ob/ob mice. The proteins were isolated as described in Methods and aliquots from the same source were immunoprecipitated with anti-peptide 80 (four left lanes) or anti-phosphotyrosine antibody (four right lanes) and immunoblotted with anti-phosphotyrosine antibody. $M_{\mathrm{r}}$ bands given at right in $A, B$, and $E$ are in $\mathrm{kD}$.

adipocytes (43). The reason for these discrepancies is not clear, but may relate to methodological differences or differences in tissues, duration or degree of diabetes, and the substrates used to measure kinase activity. Our data in STZ-diabetic rats, showed a $40 \%$ increase in the insulin receptor phosphorylation in muscle and no increase in the liver, when expressed per milligram of protein or weight of tissue. However, when the data are normalized to insulin binding, there is a decrease in receptor autophosphorylation per receptor in liver and muscle in vivo, which is in accordance with previous data on partially purified insulin receptor $(3,21,34)$.

As in fasting, the increment in IRS- 1 phosphorylation in muscle is higher than the increment in insulin receptor phosphorylation, consistent with an amplification of the insulin signal between $\beta$ subunit autophosphorylation and the phosphorylation of IRS-1. Phosphorylation of IRS-1 increases almost twofold in muscle, but not in liver, of diabetic rats. Although the mechanism(s) responsible for this tissue specific regulation of insulin receptor and IRS-1 phosphorylation is not known, changes in the activity of enzymes responsible for phosphotyrosine dephosphorylation may play a role. Our laboratory has previously shown (44) that there is an increase in both the particulate and cytosolic phosphotyrosine phosphatase activity in liver of rats made insulin-deficient diabetic by STZ. To our knowledge there is no report of phosphotyrosine phosphatase activity in muscle of STZ diabetic rats, but under most assay conditions, the levels of phosphotyrosine phosphatase are $\sim$ 10-fold higher in liver than in muscle (45).

Thus, the decrease in receptor autophosphorylation per receptor in liver and muscle of STZ diabetic animal may be of limited biological significance since receptor number increases and phosphorylation of IRS-1 is not reduced in this setting. This suggests that the insulin resistance in STZ diabetes is not at the level of IRS-1 phosphorylation. In situations where binding increases and receptor phosphorylation decreases, IRS-1 may be used as a marker of overall kinase activity in the cell. 
Table II. Regulation of Insulin Receptor and IRS-1 in Muscle and Liver in Physiologic and Pathologic States

\begin{tabular}{|c|c|c|c|c|c|c|c|c|}
\hline & \multicolumn{4}{|c|}{ Insulin receptor } & \multicolumn{4}{|c|}{ IRS-1/pp185 } \\
\hline & \multicolumn{2}{|c|}{ Binding } & \multicolumn{2}{|c|}{ Phosphorylation } & \multicolumn{2}{|c|}{ Protein } & \multicolumn{2}{|c|}{ Phosphorylation } \\
\hline & Muscle & Liver & Muscle & Liver & Muscle & Liver & Muscle & Liver \\
\hline \multicolumn{9}{|l|}{ Fasting } \\
\hline $24 \mathrm{~h}$ & 令 & $\frac{1}{2}$ & 目 & 会 & 8 & 食 & 会 & \\
\hline $48 \mathrm{~h}$ & & & & & & & & \\
\hline $72 \mathrm{~h}$ & & & & & & & & \\
\hline STZ diabetes & & & & & & & & \\
\hline
\end{tabular}

The levels of IRS-1 protein did not account for the changes in IRS-1 phosphorylation being reduced $\sim 20 \%$ in muscle and increased $\sim 30 \%$ in liver. It is important to note that as in fasting, regulation of IRS-1 protein was tissue-specific in STZ diabetes. Thus in both fasting and STZ diabetes, IRS-1 protein levels increase in liver but decrease in muscle (Table II).

A well-studied rodent model of type 2 diabetes is the ob/ob mouse. This autosomal recessive mutation in mice is characterized by obesity, hyperglycemia, hyperinsulinemia, and several metabolic defects consistent with peripheral insulin insensitivity (46). The decrease in insulin action in this model is associated with decreased receptor number $(28,33,46)$, but the activity of the receptor kinase against exogenous substrates, when corrected per insulin binding, appears to be normal (33, $47)$. Thus the major defects in this model seem to be a decrease in the number of insulin receptors and alterations at the postreceptor level.

The current study show that in vivo there is a small decrease in insulin receptor autophosphorylation in liver and a modest decrease in muscle when normalized per milligram of protein. This completely disappears or is converted to an increase in liver, if we correct the data per insulin binding. In contrast there is a significant decrease in the level of tyrosine phosphorylation in IRS-1 after insulin stimulation in liver and muscle in ob/ob mice suggesting that this may be a major factor in the insulin resistance. This is in accordance with a previous study that showed the absolute level of phosphorylation of pp185 (IRS-1) in response to insulin is lower in adipocytes from NIDDM (48).

Reduction in IRS-1 phosphorylation has also been observed in $\mathrm{CHO}$ cells expressing insulin receptors in which phenylalanine has been substituted for tyrosine 960 (29) or three phenylalanines for tyrosines 1158,1162 , and $1163(8)$. In the Phe-960 cells, the insulin binding and autophosphorylation are normal, and the absence of biological activity correlates specifically with the inability of the mutant receptor to stimulate the tyrosyl phosphorylation of IRS-1. This suggests that the phosphorylation of cellular substrate IRS-1 may be necessary for the biological activity of the insulin, even if receptor phosphorylation is normal. Thus, the reduced level of phosphorylation of IRS-1 in liver and muscle in ob/ob mice may play a role in the impaired insulin action. The decreased level of IRS-1 in liver may contribute to the reduction in tyrosyl phosphorylation of IRS-1, but in muscle the level of IRS-1 protein is normal ( Table II). Thus the decrease in IRS-1 phosphorylation appears to reflect changes in the ability of the insulin receptor to utilize this protein substrate in these cells.

One question raised by the present study is whether IRS-1 is heterogenous. The IRS- 1 band in the extracts of $\mathrm{CHO}$ cells, liver, and muscle migrate somewhat differently in SDS gels, and in mouse liver, IRS-1 appears as two discrete bands, one of which is much more markedly decreased in the ob/ob mouse than the other. Our results using sequential immunoprecipitation demonstrate that IRS- 1 and pp 185 are the same protein, at least in liver and muscle. It is likely that some of the differences in the apparent molecular mass are due to differences in serine, threonine, and/or tyrosine phosphorylation. When anti-IRS-1 antibodies were used to immunoprecipitate extracts of liver and muscle after insulin stimulation and analyzed by immunoblotting with anti-phosphotyrosine antibody, the behavior of IRS-1 phosphorylation was identical to that of the whole extract analyzed in the same blot for each of the conditions studied. Thus, IRS-1 and pp 185 are the same and show identical changes in every disease state.

Taken together, the results of these three models of insulin resistance suggest that the level of tyrosine phosphorylation of IRS- 1 in muscle is increased in situations of hypoinsulinemia in spite of decreased level of the protein (Table II). In liver, the phosphorylation of IRS-1 also increases during fasting and STZ diabetes, and these two situations are accompanied by an increase in the level of the protein. On the other hand, in obesity-associated diabetes with hyperinsulinemia, the phosphorylation of IRS-1 in liver and muscle is reduced, and this is associated with a decreased protein in liver. These data indicate that IRS-1 has a tissue specific regulation, but that IRS-1 phosphorylation depends more on insulin receptor kinase activity than IRS-1 protein levels. Our finding that the level of this protein in liver is inversely related to the insulin levels is striking and suggests that insulin may play a role in the regulation of IRS-1 expression.

In summary, this study demonstrates that the insulin resistance observed in vivo in hypoinsulinemic states like fasting and STZ diabetes is associated with increased IRS-1 phosphorylation in liver and muscle. Reduced IRS-1 phosphorylation is present in liver and muscle of ob/ob mice and in this setting may play a role in the insulin-resistant state. The regulation of the IRS-1 protein is tissue specific. In liver, insulin levels may also regulate the expression of IRS-1. Further direct studies of the hormonal effect in protein expression are needed to clarify this point.

\section{Acknowledgments}

The authors would like to thank Terri-Lyn Bellman for excellent secretarial assistance; M. Petruzzelli for technical assistance with animal care; and Drs. N. Hashimoto, K. Yamada, Franco Folli and T. Shiba for helpful discussions.

This work was supported in part by National Institutes of Health grants DK-33201 to Dr. Kahn, Joslin's Diabetes and Endocrinology Research Center grant (DK-36836), and the Marilyn M. Simpson Research Program in Diabetes (Dr. Kahn). During this work, Dr. Saad held a fellowship from the CNPq, Brazil.

\section{References}

1. Flier, J. S. 1983. Insulin receptors and insulin resistance. Annu. Rev. Med. 34:145-160. 
2. DeFronzo, R. A., R. Hendler, and D. Simonson. 1982. Insulin resistance is a prominent feature of insulin-dependent diabetes. Diabetes. 31:795-801.

3. Block, N. E., and M. G. Buse. 1989. Effects of hypercortisolemia and diabetes on skeletal muscle insulin receptor function in vitro and in vivo. $\mathrm{Am}$. J. Physiol. 256:E39-E45.

4. Balage, M., J. Grizard, C. Sornet, J. Simon, D. Dardevet, and M. Manin 1990. Insulin Binding and receptor tyrosine kinase activity in rat liver and skeletal muscle: effect of starvation. Metab. Clin. Exp. 39:366-373.

5. Kahn, C. R., and M. F. White. 1988. The insulin receptor and the molecular mechanism of insulin action. J. Clin. Invest. 82:1151-1156.

6. Kasuga, M., F. A. Karlsson, and C. R. Kahn. 1982. Insulin stimulates the phosphorylation of the 95,000-dalton subunit of its own receptor. Science (Wash. DC). 215:185-187. 1458 .

7. Rosen, O. M. 1987. After insulin binds. Science (Wash. DC). 237:1452-

8. Ellis, L., E. Clauser, D. O. Morgan, M. Edery, R. A. Roth, and W. J. Rutter. 1986. Replacement of insulin receptor tyrosine residues 1162 and 1163 compromises insulin-stimulated kinase activity and uptake of 2-deoxyglucose. Cell. 45:721-732.

9. Ebina, Y., E. Araki, M. Taira, F. Shimada, M. Mori, C. S. Craik, K. Siddle, S. B. Pierce, R. A. Roth, and W. J. Rutter. 1987. Replacement of lysine residue 1030 in the putative ATP-binding region of the insulin receptor abolishes insulinand antibody-stimulated glucose uptake and receptor kinase activity. Proc. Natl. Acad. Sci. USA. 84:704-708.

10. Chou, C. K., T. J. Dull, D. S. Russel, R. Gherzi, D. Lewohl, A. Ullrich, and O. M. Rosen. 1987. Human insulin receptors mutated at the ATP-binding site lack protein tyrosine kinase activity and fail to mediate postreceptor effects of insulin. J. Biol. Chem. 262:1842-1847.

11. Rothenberg, P., M. F. White, and C. R. Kahn. 1990. In Handbook of Experimental Pharmacology. Volume 92. (P. Cuatrecasas and S. Jacobs, editors.) Springer-Verlag, Inc., New York. 209-236.

12. White, M. F., R. Maron, and C. R. Kahn. 1985. Insulin rapidly stimulates tyrosine phosphorylation of a $M_{\mathrm{r}} 185,000$ protein in intact cells. Nature (Lond.) 318:183-186.

13. Gibbs, E. M., W. J. Allard, and G. E. Lienhard. 1986. The glucose transporter in 3T3-L1 adypocytes is phosphorylated in response to phorbol ester but not in response to insulin. J. Biol. Chem. 261:16597-16603.

14. Kadowaki, T., S. Koyasu, E. Nishida, K. Tobe, T. Izumi, F. Takaku, H. Sakai, I. Yahara, and M. Kasuga. 1987. Tyrosine phosphorylation of common and specific sets of cellular proteins rapidly induced by insulin, insulin-like growth factor I, and epidermal growth factor in an intact cell. J. Biol. Chem. 262:7342-7350.

15. Shemer, J., M. Adamo, G. L. Wilson, D. Heffez, Y. Zick, and D. LeRoith. 1987. Insulin and insulin-like growth factor-I stimulate a common endogenous phosphoprotein substrate (pp185) in intact neuroblastoma cells. J. Biol. Chem. 262:15476-15482.

16. Chou, C. K., T. J. Dull, D. S. Russel, R. Gherzi, D. Lebwohl, A. Ulrich, and O. M. Rosen. 1987. Human insulin receptors mutated at the ATP-binding site lack protein tyrosine kinase activity and fail to mediate postreceptor effects of insulin. J. Biol. Chem. 262:1842-1847.

17. White, M. F., E. W. Stegmann, T. J. Dull, A. Ullrich, and C. R. Kahn. 1987. Characterization of an endogenous substrate of the insulin receptor in cultured cells. J. Biol. Chem. 262:9769-9777.

18. Maegawa, H., J. M. Olefsky, S. Thies, D. Boyd, A. Ulirich, and D. A. McClain. 1988. Insulin receptor with defective tyrosine kinase inhibit normal receptor function at the level of substrate phosphorylation. J. Biol. Chem. 263:12629-12637.

19. Momomura, K., K. Tobe, Y. Seyama, F. Takaku, Y. Akanuma, and M. Kasuga. 1987. Insulin-induced tyrosine phosphorylation in intact rat adipocytes. Biochem. Biophys. Res. Commun. 155:1181-1186.

20. Xiao, J. S., P. Rothenberg, C. R. Kahn, J. M. Backer, E. Araki, P. Wilden, D. A. Cahill, B. J. Goldstein, and M. F. White. 1991. Structure of the insulin receptor substrate IRS-1 defines a unique signal transduction protein. Nature (Lond.). 352:73-77.

21. Kadowaki, T. M., M. Kasuga, Y. Akanumo, O. Ezaki, and F. Takaku. 1984. Decreased autophosphorylation of the insulin receptor kinase in streptozotocin-diabetic rats. J. Biol. Chem. 259:14208-14216.

22. Block, N. E., K. Komori, K. A. Robinson, S. A. Dutton, C. F. Lam, and M. G. Buse. 1991. Diabetes-associated impairment of hepatic insulin receptor tyrosine kinase activity: a study of mechanisms. Endocrinology. 128:312-322.

23. White, M. F., and C. R. Kahn. 1986. The insulin receptor and tyrosine phosphorylation. Enzymes. 17:247-258.

24. Pang, D. T., B. R. Sharma, and J. A. Shafer. 1985. Purification of the catalitically active phosphorylated form of insulin receptor kinase by affinity chromatography with $O$-phosphotyrosyl-binding antibodies. Arch. Biochem. Biophys. 242:176-186.
25. Rothenberg, P. L., W. S. Lane, A. Karasik, J. Backer, M. White, and C. R. Kahn. 1991. Purification and partial sequence analysis of pp185, the major cellular substrate of the insulin receptor tyrosine kinase. J. Biol. Chem. 266:83028311.

26. Laemmli, U. K. 1970. Cleavage of structural proteins during the assembly of the head bacteriophage T4. Nature (Lond.). 227:680-685.

27. Towbin, H., J. Staehlin, and J. Gordon. 1979. Electrophoretic transfer of proteins from polyacrylamide gels to nitrocellulose sheets: procedure and some applications. Proc. Natl. Acad. Sci. USA. 76:4350-4354.

28. Soll, A. H., C. R. Kahn, and D. M. Neville, Jr. 1974. Insulin binding to liver plasma membranes in the obese hyperglycemic (ob/ob) mouse. J. Biol. Chem. 250:4702-4707.

29. White, M. F., J. N. Livingston, J. M. Backer, V. Lauris, T. J. Dull, A Ullrich, and C. R. Kahn. 1988. Mutation of the insulin receptor at tyrosine 960 inhibits signal transmission but does not affect its tyrosine kinase activity. Cell. 54:641-649.

30. Karasik, A., and C. R. Kahn. 1988. Dexamethasone-induced changes in phosphorylation of the insulin and epidermal growth factor receptors and their substrates in intact rat hepatocytes. Endocrinology. 123:2214-2222.

31. Bradford, M. M. 1976. A rapid and sensitive method for the quantitation of microgram quantities of protein utilizing the principle of protein dye binding. Anal. Biochem. 72:248-254.

32. Almira, E. C., and W. J. Reddy. 1979. Effect of fasting on insulin binding to hepatocytes and liver plasma membranes from rats. Endocrinology. 104:205211.

33. Vicario, P., E. J. Brady, E. E. Slater, and R. Superstein. 1987. Insulin receptor tyrosine kinase activity is unaltered in $\mathrm{ob} / \mathrm{ob}$ and $\mathrm{db} / \mathrm{db}$ mouse skeletal muscle membranes. Life Sci. 41:1233-1241.

34. Tobe, K., O. Koshio, Y. Tashiro-Hashimoto, F. Takaku, Y. Akanuma, and M. Kasuga. 1990. Immunological detection of phosphotyrosine-containing proteins in rat livers after insulin injection. Diabetes. 39:528-533.

35. Okamoto, M., M. F. White, R. Maron, and C. R. Kahn. 1986. Autophosphorylation and kinase activity of insulin receptor in diabetic rats. Am. J. Physiol. 251:E542-550.

36. Kathuria, S., S. Hartman, C. Grunfeld, J. Ramachandran, and Y. Fujita Yamaguchi. 1986. Differential sensitivity of two functions of the insulin receptor to the associated proteolysis: kinase action and hormone binding. Proc. Natl. Acad. Sci. USA. 83:8570-8574.

37. Sweet, L. J., D. J. Dudley, J. Pessin, and A. Spector. 1987. Phospholipid activation of the insulin receptor kinase: regulation by phosphatidylinositol. $F A$ SEB (Fed. Am. Soc. Exp. Biol.) J. 1:55-59.

38. Fehlman M., J. Peyron, M. Samson, E. Van Obberghen, D. Brandenburg, and N. Brossete. 1985. Molecular association between major histocompatibility complex class I antigens and insulin receptors in mouse liver membranes. Proc. Natl. Acad. Sci. USA. 82:8634-8637.

39. Friedenberg, G., H. H. Klaein, R. Cordera, and J. Olefsky. 1985. Insulin receptor kinase activity in rat liver: regulation by fasting and high carbohydrate feeding. J. Biol. Chem. 260:12444-12453.

40. Penicaud, L., J. Kande, and J. Le Magnen. 1985. Insulin action during fasting and refeeding in rat determined by euglycemic clamp. Am. J. Physiol. 249:E514-E518.

41. Charron, J. M., and B. B. Kahn. 1990. Divergent molecular mechanisms for insulin-resistant glucose transport in muscle and adipose cells in vivo. J. Biol. Chem. 265:7994-8000.

42. Amatruda, J. M., and M. Roncone. 1985. Normal hepatic insulin receptor autophosphorylation in nonketotic diabetes mellitus. Biochem. Biophys. Res. Commun. 129:163-170.

43. Truglia, J. A., G. R. Hayes, and D. H. Lockwood. 1988. Intact adipocyte insulin-receptor phosphorylation and in vitro tyrosine kinase activity in animal models of insulin resistance. Diabetes. 37:147-153.

44. Meyerovitch J., J. M. Backer, and C. R. Kahn. 1989. Hepatic phosphotyrosine phosphatase activity and its alterations in diabetic rats. J. Clin. Invest. 84:976-983.

45. Sale, J. G. 1991. Insulin receptor phosphotyrosyl protein phosphatase and the regulation of insulin receptor tyrosine kinase action. Adv. Protein Phosphatases. 6:159-186.

46. Mordes, J. P., and A. A. Rossini. 1985. Animal models of diabetes mellitus. In Joslin's Diabetes Mellitus. A. Marble, L. P. Krall, R. F. Bradley, H. R. Christlieb, and J. S. Soeldner, editors. Lea \& Febiger, Philadelphia. 110-137.

47. Tannti, J. F., T. Gremeaux, E. Brandenburg, E. Van Obberghen, and Y. L. Marchand-Brustel. 1986. Brown adipose tissue in lean and obese mice. Diabetes. 35:1243-1248.

48. Thies, R. S., J. M. Molina, T. P. Ciaraldi, G. R. Freidenberg, and J. M. Olefsky. 1990. Insulin-receptor autophosphorylation and endogenous substrate phosphorylation in human adipocytes from control, obese, and NIDDM subjects. Diabetes. 39:250-259. 